\title{
ПСИХОЛОГО-ПЕДАГОГІЧНІ ОСОБЛИВОСТІ ОРГАНІЗАЦІЇ САМОСТІЙНОЇ РОБОТИ СТУДЕНТІВ В УМОВАХ НАВЧАННЯ ЗА ЕСТS
}

Матеріали присвячені висвітленню проблеми інтенсифікації самостійної роботи студентів як одного із центральних напрямків перебудови навчання у вищій школі Украӥни. Аналізуються наукові дослідження з питань впливу самопідготовки на особистісний $і$ професійний розвиток молодої людини. Описуються результати тривалого спостереження за самостійною роботою студентів різних напрямків підготовки. Наголошується, що в умовах реалій сучасного професійного життя від молодого фахівия вимагається готовність до інічіативного, творчого прийняття професійних рішень, розвинених пізнавальних позицій, готовності продовжувати навчання $i$ по завершенню навчання у закладі вищої освіти.

Ключові слова: самореалізаџія, пізнавальна позииія, самостійність, навчальна діяльність студента, самостійна робота, самопідготовка.

Материаль статьи посвящены освещению проблемы интенсификации самостоятельной работы студентов, как одного из ведущих направлений перестройки обучения в высшей школе Украины. Анализируются научные исследования по вопросу влияния самоподготовки на личностное и профессиональное развитие студентом. Описываются результаты длительного наблюдения за самостоятельной работой студентов различных направлений профессиональной подготовки. Подчеркивается, что в условиях современных реалий профессиональной жизни от начинающего спещиалиста требуется готовность к инициативному, творческому принятию профессиональных решений, наличию развитой познавательной позиции, готовности продолжать обучение и по завершению обучения в вузе.

Ключевые слова: самореализация, познавательная позиция, самостоятельность, учебная деятельность студента, самостоятельная работа, самоподготовка.

Постановка проблеми. Зміна парадигми вищої освіти в Україні зорієнтована на забезпечення особистісної самореалізації майбутнього фахівця в освітньому просторі вищого навчального закладу. Його високий рівень активності, творчості, ініціативності - важлива умова професійного зростання. Необхідність впровадження нормованої самостійної роботи студентів з різних навчальних дисциплін в умовах ECTS робить дослідження одним із важливих завдань сучасної психолого-педагогічної науки та вузівської практики. Адже, оптимальна організація позааудиторної роботи студентів передбачає науково обгрунтування самостійних завдань, а також вдосконалення методики ї виконання.

Аналіз останніх досліджень і публікацій. У вітчизняній психолого-педагогічній науці дослідження організації самостійної роботи студентів представлено як: один із шляхів оволодіння професійними компетентностями (А. А. Орлов) [5]); спосіб розвитку пізнавальної позиції та пізнавальної стратегії (О. В. Чукаєв [6]); стратегія регулювання та інтегрування обсягу самостійної роботи із усіх дисциплін (О.В. Неценко, В. Д. Стойков); аналіз складності та обсягу самостійних завдань (Н. Н. Водомєров [2]); спроба обгрунтувати вільний час для творчого зростання студента (Ю. Леонавічус); дослідження розвитку суб’єктності студентів в умовах вищої школи [4].

Випуск 11, 2018. Збірник наукових праць РДГУ 
Самостійна робота студента в умовах ECTS є основним засобом засвоєння навчального матеріалу у вільний від аудиторних занять час. Вона включає: опрацювання навчального матеріалу, підготовку до навчальних занять, виконання індивідуальних завдань, підготовку атестаційної роботи, науково-дослідну роботу тощо. Навчальний час, відведений на самостійну роботу студента денної форми навчання, регламентується робочим навчальним планом і складає, як правило, від $1 / 3$ до 2/3 від загального обсягу навчального часу, відведеного на вивчення конкретної дисципліни. Під час планування часу самостійної роботи студентів рекомендується одна година СРС на кожну лекцію. Для підготовки до: практичного заняття - 1-2 години; лабораторної роботи, комп'ютерного практикуму - 2-3 години; семінарського заняття, контрольної роботи - 2-4 години; заліку - 6 годин; екзамену - 30 годин.

Зміст самостійної роботи студента із конкретної теми визначається робочою програмою, методичними матеріалами, завданнями та вказівками науково-педагогічного працівника.

Формулювання цілей статті. Метою дослідження є обгрунтування оптимальної організації самостійної роботи студента із різних навчальних дисциплін протягом семестру, а також використання творчих завдань, які, імпонують студенту, відповідають його інтересам та уподобання.

Для досягнення мети вирішуються такі завдання: дослідити використання студентами різних курсів та спеціальностей додаткової літератури; вплив самостійної роботи на якість знань студентів; стимули для використання різних форм самостійної роботи; встановити час, який фактично витрачається студентами на виконання самостійної роботи

Виклад основного матеріалу дослідження. До раціонально організованої самостійної роботи відноситься не лише вимога навчити студента оволодіти знаннями через освітній процес, але й сформувати вміння самостійно здобувати знання після закінчення вузу, розвинути його суб'єктність та пізнавальну позицію [6]. Тому у психологічній та педагогічній літературі не раз наголошувалося на тому, що самостійну роботу студента не можна пускати на самотік, вона повинна організовуватися і належним чином контролюватися.

Оптимальна організація самостійної роботи передбачає науково обгрунтоване формування обсягу самостійних занять. Однак, на практиці часто відсутня координація обсягу обов'язкових робіт студентів у межах структурних підрозділів вузу, порушується система планування практичних та семінарських занять, що призводить до перенавантаження студентів в окремі дні та тижні. Встановити оптимальний обсяг самостійної роботи не так і легко: важко визначити складність та обсяг завдань та відрегулювати його за всіма дисциплінами семестру (О. В. Неценко, В. Д. Стойков, Н. Н. Водомєров).

Практика свідчить, що окрім обов'язкового обсягу робіт - частина найкращих студентів займається додатково: виконує дослідження, вивчає іноземні мови, відвідує різноманітні курси, читає додаткову літературу.

Згідно наших спостережень, більше половини студентів старших курсів (третій - четвертий курс) працюють із додатковою літературою за спеціальності. Все ж ставлення до цього типу активності у студентів різних факультетів різниться (див. рис. 1).

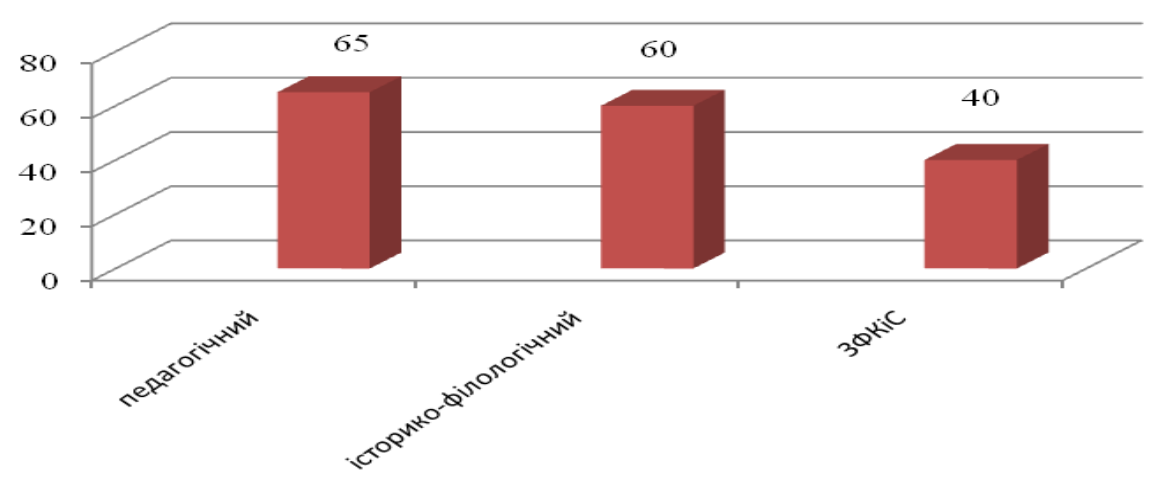

\section{Рис.1. Кількісні показники обсягу підгруп студентів різних факультетів В3О, які зоріснтовані на використання додаткової літератури при вивченні навчальних дисциплін}

Як видно з рис 1. пошук інформації у наукових джерелах, які не входять до обов'язкових переліків не є нормою для усього студентства. Це засвідчує необхідність стимулювання їх самостійності та ініціативності. Розвиток цих якостей допоможе молодій людині не лише успішно 
засвоювати матеріал, а й стати у майбутньому творчим фахівцем, який здатний відповідати запитам сьогодення.

Спроби обгрунтовано проаналізувати часові показники творчого зростання студента пропонує Ю. Леонавічус. До розділу «Вільний час» він відносить такі складові: витрата часу на поглиблення знань; суспільно-корисна праця; творча діяльність; фізична культура та спорт; відпочинок та розваги. Витрата часу на поглиблення знань, у свою чергу, включає: читання наукових книг, періодики; підготовку наукових доповідей та повідомлень; участь у науково-теоретичних конференціях, перегляд спеціальних теле- та радіопередач, фільмів. Види цих занять - не є обов'язковими, однак їх значення у формуванні спеціалістів досить суттєве. Тому всі види робіт, виділені Ю.І. Леонавічусом у складовій «Витрата часу на поглиблення знань» - повинні входити в бюджет робочого часу студента.

Формуюча сторона самостійної роботи, на жаль, мало враховується на практиці. Тому ми спробували проаналізувати цей процес упродовж одного семестру навчання студента у вищому закладі. Разом із кураторами академічних груп ми провели вивчення самостійної роботи студентів. Спостереження передбачало як вивчення самопідготовки до занять, так і роботу студентів в аудиторному режимі. За результатами спостереження було встановлено, що більшість студентів (58,2 відсотків) сумлінно ставляться до навчання (див. рис.2).

Ми можемо констатувати, що їх самостійна робота систематична i творча. Третина респондентів (29,4 відсотки) була віднесена нами до підгрупи «готуються до занять епізодично». із них готуються до занять систематично, Все ж варто визнати, що частина наших студентів $(11,8$ відсотка) обрала неефективний шлях професійного становлення.

Ставлення до навчання чітко позначилося на якісних характеристиках навчальної діяльності студентів. Зокрема студенти першої підгрупи навчилися вільно висловлювати думки, проявляти креативність у вирішенні завдань . У них сформувався стійкий інтерес до занять. У підгрупі респондентів, які епізодично готувалися до занять, простежувалася схильність відтворювати на практичних і семінарських заняттях лише матеріали лекційних занять. Їх ставлення до навчання у цілому можна охарактеризувати як нейтральне.Таким чином, наші спостереження підтвердили, що якість самостійної роботи та іï систематичність позначається як на рівні засвоєння знань, так i інтересі до навчальних предметів.

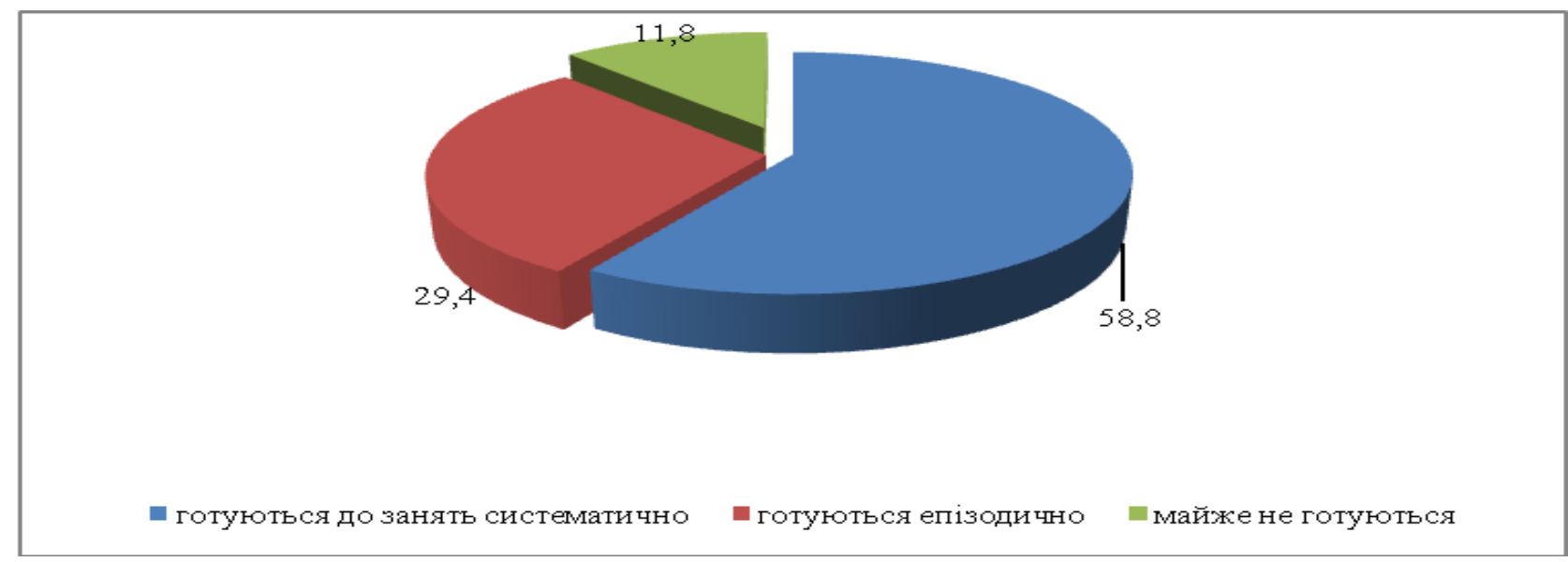

\section{Рис.2. Кількісні показники підгруп студентів із різним ставленням до навчання та самостійної підготовки}

Самостійна робота виховує у студентів уміння мислити, кресативно сприймати інформацію. 3 іншого боку - інтерес до предмету полегшує його засвоєння. Саме такий взаємозв'язок і стимулює у подальшому самостійну роботу студентів, що перетворює іiі в потребу. Досвід дає можливість зробити рекомендації викладачам. Основний стимул для самостійної роботи створюється під час лекції шляхом постановки проблеми. Саме проблематична лекція спонукає студентів до необхідності працювати самостійно. Вона не підміняє самостійну роботу студента, а спрямовує іiі та стимулює. Наші спостереження показали, що 70 \% студентів других-четвертих курсів педагогічного факультету, де проводилося дослідження, віддавали перевагу завданням творчого характеру (підготовка презентацій, розв’язання психолого-педагогічних задач, підготовка до дискусій). 
Як відомо, офіційний робочий день студента, який складається з обов'язкових занять складає шість годин. Розподіл часу студента - це одна із проблем психології і педагогіки вищої школи. Аналіз бюджету часу студентів у тривалій часовій перспективі (протягом п'яти років) дозволив нам зробити певні узагальнення з цього питання. На основі отриманих даних ми узагальнили час, який витрачають студенти на основні види діяльності: обов'язкові заняття - 26 годин на тиждень, самостійної роботи - 18 годин. Нами було встановлено, що студенти-філологи щоденно витрачають на самоосвіту 3,5 години, студенти педагогічного факультету - 4 години, студенти факультету ЗФКіС - 3 години. Однак протягом семестру цей час використовується студентами нерівномірно. Так, 3 лекційними матеріалами регулярно працює $70 \%$ першокурсників, 50 \% - студентів другого курсу, 30 $\%$ - студенти третього курсу. Кількість таких студентів четвертого курсу складає 33 \%. Регулярно до практичних занять готується 70 \% першокурсників, 70 \% студентів другого курсу і 65, 60 \% відповідно студентів третього та четвертого курсу. Тривалість самостійної роботи змінюється протягом семестру: на початку вона помірна, коли починаються практичні заняття - по 3 години на день, у кінці семестру, під час заліків воно становить 3, 5-4 години. Виникає питання: як розподілити ці 3-4 години самостійної роботи на предмети, які вивчаються протягом семестру. Враховуючи результати опитування студентів протягом декількох років, можемо відзначити, що на дисципліни циклу загальної підготовки студенти витрачають 2 години на день, на дисципліни циклу професійної підготовки - 3- 4 години.

Висновки та перспективи подальших розвідок. Отже, проаналізувавши ставлення студентів до навчання, їх уміння розподіляти час та здійснювати самостійну підготовку до навчальних занять, можемо зробити наступні висновки:

- в умовах реалізації нової парадигми освіти, самостійна робота, студента, його ініціативність та творчість виступають наріжним каменем у підготовці конкурентоспроможного фахівця;

- здатність студента до організації власної навчальної активності не завжди відповідає вимогам сьогодення;

- готовність студента до самореалізацію у навчальній діяльності значною мірою залежить від вдалого педагогічного супроводу цього процесу зі сторони викладачів;

- самостійну роботу студента з вивчення навчального матеріалу не варто зводити лише для виконання завдань нормативного характеру. Творча активність та самостійність починається вже в аудиторії, коли студент не просто занотовує тексти лекцій, а й взаємодіє із викладачем на «суб'єктсуб'єктному рівні».

Наші спостереження засвідчують, що рівень самостійності студента у навчальній діяльності значною мірою пов'язаний з пізнавальними інтересами та професійною мотивацією. Значну роль у навчальній діяльності старшокурсників має пошукова діяльність, розв'язання завдань творчого характеру, оскільки вони забезпечують особистісну самореалізацію. Тому студенти старших курсів більше цікавляться дослідницькою діяльністю, їм довподоби завдання творчого характеру. Важливу роль у розвитку самостійності та особистісної відповідальності студентів у навчальній діяльності відіграє принцип системності.

\section{Список використаних джерел}

1. Бендера I. М. Організація самостійної роботи студентів агро інженерних спеціальностей : монографія / І. М. Бендера. - Київ : Наук. центр аграр. освіти, 2007. - 364 с.

2. Водомеров Н.Н. Свободное время студента / Н. Н. Водомеров // Эффективность подготовки специалиста : сб. науч. тр. - Киев : Высшая шк., 1997. - С. 272.

3. Герасименко Н. О. Дидактичні умови організації самостійної роботи студентів педагогічних університетів в процесі навчання іноземних мов : дис. ... канд. пед. наук : 13.00 .09 / Н. О. Герасименко. - Кривий Ріг, 2012. - 215 с.

4. Исаев Е. И. Психология развития субъектности студентов в образовательном процессе высшей школы в контексте компетентностного подхода / Е. И. Исаев, Н. Е Исаева // Проектирование и организация самостоятельной работы студентов в контексте компетентностного подхода : межвуз. сб. науч. тр. / под ред. А. А. Орлова. - М. : Директ-Медиа, 2014. - Вып. 1. - С. 90-121.

5. Орлова А. А. Развитие субъектности студента как основа проектирования самостоятельной работы / А.А. Орлова // Проектирование и организация самостоятельной работы студентов в контексте компетентностного подхода : межвуз. сб. науч. тр. / под ред. А. А. Орлова. - М. : ДиректМедиа, 2014. - Вып. 1. - С. 122-135.

6. Чукаев О.В. Познавательная позиция и познавательные стратегии студентов в самостоятельной работе как основа развития профессиональной компетентности будущих учителей / 
О. В. Чукаев // Проектирование и организация самостоятельной работы студентов в контексте компетентностного подхода: межвуз. сб. науч. тр. / под ред. А. А. Орлова. - М. : Директ-Медиа, 2014. - Вып. 1. - С. 190-212.

\section{References}

1. Bendera I. M. Organizaciya samostijnoyi roboty` studentiv agro inzhenerny`x special `nostej: monografiya / I. M. Bendera. - Kiyev : Nauk. centr agrar. osvity`, 2007 - 364 s

2. Vodomerov N. N. Svobodnoye vremya studenta / N. N. Vodomerov // Effektivnost podgotovki spetsialista : sb. nauch. tr. - Kiyev : Vissh. shk., 1997. - S. 272.

3. Gerasymenko N. O. Dydaktychni umovy organizaciyi samostijnoyi roboty studentiv pedagogichnyx universytetiv $\mathrm{v}$ procesi navchannya inozemnyx mov : dys. ... kand. ped. nauk : 13.00.09/ N. O. Gerasymenko. - Kryvyy Rih, 2012. - 215 s.

5 Isayev E. I. Psikhologiya razvitiya subyektnosti studentov v obrazovatelnom protsesse vysshey shkoly v kontekste kompetentnostnogo podkhoda / E. I. Isayev. N. E Isayeva // Proyektirovaniye i organizatsiya samostoyatelnoy raboty studentov $\mathrm{v}$ kontekste kompetentnostnogo podkhoda : mezhvuz. sb. nauch. tr. - M. : Direkt-Media, 2014. - Vyp. 1. - S. 90-121.

6. Orlova A. A. Razvitiye subyektnosti studenta kak osnova proyektirovaniya samostoyatelnoy raboty / A. A. Orlova // Proyektirovaniye i organizatsiya samostoyatelnoy raboty studentov v kontekste kompetentnostnogo podkhoda : mezhvuz. sb. nauch. tr. - M. : Direkt-Media, 2014. - Vyp. 1. - S. 122-135.

6. Chukayev O. V. Poznavatelnaya pozitsiya i poznavatelnyye strategii studentov v samostoyatelnoy rabote kak osnova razvitiya professionalnoy kompetentnosti budushchikh uchiteley / O. V. Chukayev // Proyektirovaniye i organizatsiya samostoyatelnoy raboty studentov $\mathrm{v}$ kontekste kompetentnostnogo podkhoda : mezhvuz. sb. nauch. tr. - M. : Direkt-Media, 2014. - Vyp. 1. - S. 190-212.

\section{O. Y. Yanytska, O. V. Ivaniuta PSYCHOLOGICAL \& PEDAGOGICAL FEATURES OF STUDENTS' INDEPENDENT WORK ORGANIZATION IN ECTS LEARNING CONDITIONS.}

Materials are devoted to the problem of students' independent work intensification as one of the central directions of education restructuring in higher school of Ukraine. Scientific research concerning the impact of self-training on the personal and professional development of a young person has been analyzed. The results of long-term observation over the students' independent work of different preparation directions have been described. It has been emphasized that in conditions of realities of the modern professional life, the readiness to initiative, creative decision-making, developing cognitive positions, readiness to continue training and completion of training at the higher educational establishments are required from the young specialist.

Thesis discusses psychological and pedagogical issues of the students' independent work organization; it highlights the issues concerning coordination of educational loads in various disciplines. It has been noted that a significant part of students do not attach due importance to the systematic selftraining, which affects the effectiveness of their training. Proposals to intensify the independent work of students have been indicated in conclusions.

Key words: self-realization, cognitive position, independence, student's educational activity, independent work, self-training. 